\title{
Penyimpangan Psikologis Tokoh Cerita Kukila (Rahasia Pohon Rahasia) Karya M. Aan Mansyur
}

\author{
Rina Kartika ${ }^{\text {* }}$ \\ David Setiadi ${ }^{1 *}$ \\ Tanti Agustiani ${ }^{*}$ \\ ${ }^{1}$ Universitas Muhammadiyah Sukabumi, \\ Sukabumi, Jawa Barat, Indonesia \\ *email: rinakartika1634@gmail.com
}

Received: 22 Juli 2020

Accepted: 29 September 2020

Published: 30 September 2020

doi: $10.22236 /$ imajeri.v3i1.5303

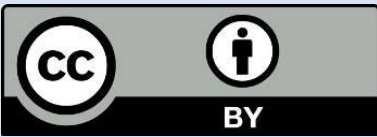

(C) 2020 Oleh authors. Lisensi Imajeri: Jurnal Pendidikan Bahasa dan Sastra Indonesia, Uhamka, Jakarta. Artikel ini bersifat open access yang didistribusikan di bawah syarat dan ketentuan Creative Commons Attribution (CC-BY) license.

(http://creativecommons.org/licenses/by/4.0/)

\begin{abstract}
Abstrak
Penyimpangan psikologis merupakan perilaku yang menyimpang dari perilaku yang biasa dilakukan oleh manusia. Di dalam novel hal tersebut sering dimunculkan melalui dinamika tokoh-tokohnya. Untuk mengetahui hal tersebut, maka penelitian ini bertujuan untuk mengetahui penyimpangan tokoh perempuan yang bernama Kukila pada novelet yang berjudul Kukila (Rahasia Pohon Rahasia) karya M. Aan Mansur. Metode penelitian yang digunakan deskriptif kualitatif yaitu mendeskripsikan penyimpangan psikologis yang terdapat di dalam novel. Berdasarkan hasil penelitian ini ditemukan empat penyimpangan psikologis yaitu: depresi, oppressed, axienty, dan adultery serta enam faktor penyebab penyimpangan psikologis.
\end{abstract}

Kata kunci: Penyimpangan Psikologis; Novelet; Kukila

\begin{abstract}
Psychological deviations are behaviors that deviate from the behavior commonly carried out by humans. In novels, this often appears through the dynamics of the characters. To find out this, this study aims to determine the deviation of a female character named Kukila in the novelet entitled Kukila (Secret Tree Secret) by M. Aan Mansur. The research method used is descriptive qualitative, namely describing the psychological deviations contained in the novel. Based on the results of this study, four psychological deviations were found, namely: depression, oppressed, axialy, and adultery as well as six faktors that cause psychological deviations.
\end{abstract}

Keywords: Psychological Deviation; Novelet; Kukila

\section{PENDAHULUAN}

Menurut Wicaksono (2017) karya sastra merupakan masalah yang dialami oleh manusia. Tentang makna hidup dan kehidupan, melukiskan penderitaan manusia, perjuangan, kasih sayang, kebencian, nafsu dan segala yang dialami oleh manusia.Sastra merupakan karya fiksi yang memiliki pemahanan yang luas bagi pembaca, bukan hanya cerita fiksi yang ditulis dari khayalan atau angan-angan yang dituangkan kedalam sebuah karya sastra dan kekreatifan pengaran dalam mengolah ide pikirannya. Purba (2010) mengungkapkan bahwa karya sastra merupakan masalah hidup, filsafat dan ilmu tentang jiwa. Sastra juga dimaknai sebagai representasi kehidupan manusia yang penuh masalah kompleks (Anwar, 2007; Dewi \& Hidayatullah, 2018; Hikmat, Puspitasari, \& Hidayatullah, 2017) 
Menurut Wiyatmi (2011) perkembangan kajian sastra yang bersifat interdisipliner telah berkembang menjadi berbagai ilmu seperti psikologi sastra, sosiologi, antropologi, gender dan sejarah pertemuan tersebut melahirkan telah melahirkan bermacam-macam pendekatan dalam kajian sastra anatra lain, psikologi sastra, sosiologi sastra, antropologi sastra, kritik sastra feminis, dan new historicism.

Perkembangan sastra juga melahirkan berbagai kerangka teori yang dikembangkan dan dihubungkan antara sastra dengan yang lain, seperti psikoanalisis/psikologi sastra, psikologi pengarang (Hikmat et al., 2017). Psikologi pembaca, sosiologi karya sastra, juga strukturalisme genetik, dan sastra marxisme. Sastra psikologi merupakan salah satu kajian dalam bidang sastra yang dapat dibaca dan diinterprestasikan hasilnya dalam karya sastra pengarang dan pembaca dengan berbagai konsep dan teori dalam bidang sastra (Wiyatmi, 2011). Dalam sastra psikologi mempunyai beberapa pengertian yaitu pengertian pertama ialah sebuah studi sastra psikologi pengarang untuk diri sendiri, pengertian yang kedua yaitu sebagai studi kreatif yang dibuat atau dapat dianalisis oleh pengarang untuk pembaca, ketiga yaitu tipe studi dan tipe hukum yang berkaitan erat dengan psikologi yang diterapkan dalam karya sastra. Hal keempat yaitu mempelajari tentang dampak dari karya sastra pada pembaca atau dapat dikatakan hal-hal yang berkaitan dengan psikologi pembaca. Psikologi dalam karya sastra mencakup tokoh-tokoh yang terdapat pada drama dan novel dinilai dari apakah benar secara psikologis (Andrian \& Rifai, 2018; Lestari, 2020; Wellek \& Warren, 1990). Situasi dan plot tertentu dipuji karena hal seperti ini kadang-kadang mempunyai teori psikologi tertentu yang digunakan oleh pengarang secara sadar atau samar-samar oleh pengarang dan teori ini cock untuk menjelaskan tokoh dan situasi cerita.

Penyimpangan psikologis merupakan sebuah perilaku yang menyimpang pada diri seseorang. Perilaku menyimpang tersebut dapat terjadi karena terdapat beberapa faktor yang terjadi dalam psikis seseorang. Penyimpangan juga bisa dipengaruhi oleh keadaan lingkungan sekitar yang membuat keadaan psikis seseorang menjadi terganggu. Dalam cerita yang berjudul Kukila (Rahasia Pohon Rahasia) terdapat empat penyimpangan dan enam faktor penyebabnya yaitu, (1) Depresi pada bagian depresi ditemukan wujud penyimpangannya yaitu, rasa bersalah yang mendalam, ditolak oleh anak, hidup sendirian didalam rumah dan juga kenangan yang menghantuinya. (2) Axienty Penyimpangan psikologi anxiety ditemukan suatu ancaman yang mengancam kenyamanan seseorang atau kecemasan yang di alami oleh Kukila pada surat yang ditulis dan dikirimkan untuk anakanaknya. (3) Oppressed Penyimpangan psikologi oppressed yaitu tentang pernikahan Kukila dengan Rusdi yang merupakan lelaki pilihan ayahnya. Konflik terjadi setelah dua tahun menikah Kukila belum memiliki seorang anak. Oppressed adalah kondisi psikologi yang mengalami tekanan dari berbagai pihak yang membuat pribadi tidak merasa nyaman dan terkenan akan yang diucapkan. (4) Adultery merupakan penyimpangan yang terjadi atas permintaan yang dilakukan oleh seseorang. Faktor penyebabnya yaitu (1) faktor rumah tangga yang dimana pemicu permasalahannya yiatu sebuah perceraian . (2) faktor psikologi yaitu faktor yang menjadikan dirinya sebagai seseorang yang salah atas kejadian yang telah terjadi. (3) faktor keluarga yaitu faktor yang menjadikan tekanan dalam hubungan ru,ah tangga yang jalin baik itu dari keluarga A ataupun keluarga B. (4) faktor 
agama yaitu faktor keyakinan diri kita sendiri dalam mempunyai keyakinan dalam hidup dan tujuan. (5) faktor seksual faktor yaitu faktor yang menjadi pemicu perceraian dalam rumah tangga yang dimana jika salah satu dari pasangan tidak memiliki keinginan atau nafsu. (6) faktor sosial yaitu faktor dalam lingkungan yang ada disekeliling hidup kita baik atau buruk itu berpengaruh dalam kehidupan rumah tangga.

Dalam bidang sastra penyimpangan psikologi dibagi menjadi dua yaitu psikologi abnormal dan abnomalitas seksual. Arti dari psikologi abnormal yaitu tentang kehidupan yang normal namun memiliki masalah tentang kecemasan yang di alami oleh diri sendiri. sedangkan abnormalitas seksual menurut Kartono (1992) seks abnormal terjadi karena adanya suatu dorongan yang membuat seseorang melakukan tindakan yang abnormal seperti prostitusi,adultery, promiscuity, seduksi dan tindakan pemerkosaan serta nymphomania dan satyriasis atau satyromania.

Menurut Diana (2002) mengatakan bahwa penyimpangan terdapat berbagai macam penyimpangan seperti halnya penyimpangan seksual itu terdapat berberapa macam jenis penyimpangan diantaranya yaitu, Gay atau biasa dibilang dengan sebutan penyuka sesama jenis kelamin laki-laki. Kedua yaitu, Lesbian atau perempuan sesama jenis yang saling menyukai. Ketiga yaitu Nekrofilia atau orang yang suka berhubungan dengan orang yang sudah meninggal (mayat). Kempat yaitu, Zoofilia adalah seseorang yang berhubungan bukan dengan manusia melainkan dengan hewan yang mereka sukai. Kelima yaitu Pedofilia atau yang sering kita dengan dengan sebutan fedofil yaitu yang dimana seeseorang berhubungan dengan anak-anak dibawah umur dan masih ada yang lainnya tentang penyimpangan psikologi.

Penelitian ini berfokus pada genre prosa. Dalam teks prosa terdapat tokoh-tokoh yang berperan sebagai pelaku cerita. Tokoh-tokoh tersebut mempunyai kapasitas baik psikologis, fisiologis, ataupun sosiologis yang dapat digunakan untuk menjalankan perannya dalam karya sastra. Tokoh perempuan sering dihadirkan pengarang sebagai bagian dalam sebuah karya sastra. Tokoh perempuan adalah sosok yang selalu memiliki daya tarik tersendiri untuk diceritakan. Hal lain yang melekat pada diri perempuan yang menjadi daya tarik sendiri untuk dibahas baik dari segi fisik, psikologis, agama, budaya dan permasalahan perempuan yang selalu muncul dalam dirinya. Pengarang biasanya menggambarkan kehidupan perempuan-perempuan berdasarkan sikap hidup, keadaan, yang dialami cara pandang perempuan dan kedudukan tokoh perempuan.

Penelitian sebelumnya yang menggunakan cerita kukila pernah dilakukan oleh Denisha (2019) dengan judul Habitus Maskulinitas Dalam Cerita Pendek "KUKILA" karya M. Aan Mansyur: Prespektif Pierra Bourdieu. Dalam penelitiannya Denisha menjelaskan bahwa habitus maskulinitas terdapat dalam cerita pendek yang berjudul Kukila karya M. Aan Mansyur, karena di dalam cerita tersebut terdapat enam maskulinitas. Denisha juga mempunyai tujuan yaitu mengkaji dan mendeskripsikan struktur sastra dalam cerita pendek serta gambaran habitus maskulinitas yang terdapat dalam cerita pendek yang berjudul Kukila karena tokoh-tokoh dalam cerita Kukila merupakan korban dari dominasi maskulinitas.

Penelitian lainnya yang menggunakan teori penyimpangan pernah dilakukan oleh Herlina Tien Suhesti (2006) dengan judul Aspek Penyimpangan Seksual dalam Kumpulan 
Cerpen Rendezvous, Kisah Yang Tak Setia Karya Agus Noor (Sebuah Kajian Psikologi Sastra). Dalam penelitiannya Herlina menjelaskan bahwa terdapat beberapa penyimpangan dalam cerita tersebut mengenai seks dan juga percintaan yang di alami tokoh-tokoh dalam cerpen tersebut. Lalu Herlina juga mempunyai tujuan yaitu tentang keadaan psikologis yang terjadi dalam cerpen tersebut karena dalam tujuannya penelitian herlina menekankan tentang seksual dan juga percintaan yang menyimpang yang dialami oleh tokoh-tokoh dalam cerpen tersebut.

Berdasarkan penelitian sebelumnya, penelitian ini berbeda dari yang telah dilakukan oleh Denisha dan Suhesti. Penelitian ini berfokus pada gambaran penyimpangan dan faktor penyimpangan yang dialami tokoh perempuan yang bernama Kukila. Oleh karena itu, penelitian ini diberi judul Penyimpangan Psikologis Tokoh Perempuan pada Cerita Kukila (Rahasia Pohon Rahasia) karya M. Aan Mansyur.

\section{METODE}

Menurut Sugiyono (2016) metode penelitian adalah cara ilmiah untuk menemukan data dengan tujuan dan kegunaan tertentu. Metode yang digunakan dalam penelitian ini adalah metode kualitatif. Metode penelitian kualitatif sering disebut penelitian naturalistik karena penelitiannya pada kondisi yang alamiah (natural setting), dalam penelitian kualitatif kegiatan penyediaan data merupakan kegiatan yang berlangsung secara bersamaan dengan kegiatan analisis data (Endraswara, 2011; Semi, 2012; Sugiyono, 2016). Analisis kualitatif berfokus kapada penunjukkan makna, deskripsi, penjelasan dan penempatan data pada konteksnya masing-masing dan menuangkannya dalam bentuk kata dari pada angka.

Metode penelitian deskriptif adalah sebuah metode yang digunakan untuk mendeskripsikan menginterpretasikan suatu penomena dengan menggunakan prosedur ilmiah untuk menjawab masalah secara aktual. Penelitian ini meneliti penyimpangan psikologis tokoh perempuan pada cerita Kukila (Rahasia Pohon Rahasia) karya M. Aan Mansyur untuk itu menurut penulis metode ini sesuai dengan penelitian yang dilakukan oleh penulis karena dengan penelitian ini penulis berusaha menjelaskan tentang penyimpangan psikologis yang dialami tokoh perempuan pada cerita Kukila (Rahasia Pohon Rahasia) tersebut. Dalam penelitian ini M. Aan Mansyur menjadi subjek penelitian, dan yang menjadi objeknya yaitu karyanya yang berjudul Kukila Kumpulan Cerita yang di dalamnya terdapat 1 cerita novelet dan 15 cerita pendek. Dalam penelitian ini peneliti mengambil 1 cerita novelet yang berjudul Kukila (Rahasia Pohon Rahasia).

Dalam teknik pengumpulan data peneliti menggunakan data primer. Data primer yang diperoleh yaitu dari membaca dan mencatat. Adapun langkah yang dilakukan yaitu dengan cara membaca terlebih dahulu cerita tersebut dan mencatatnya. Langkah pertama yang dilakukan yaitu dengan cara membaca teks berulang kali serta memberi tanda tertang adanya penyimpangan serta faktor dan penyebab terjadinya penyimpangan psikologis pada tokoh perempuan. Selanjutnya yaitu memahami isi dari teks cerita tersebut dan memberi tanda dibagian yang menjadi penyimpangan psikologis serta faktor penyebab terjadinya penyimpangan psikologis pada tokoh perempuan tersebut, sebagaimana yang tulis dalam 
tujuan penelitian yaitu untuk mengetahui penyimpangan psikologis setra faktor dan penyebab terjadinya penyimpangan psikologis yang dialami tokoh perempuan yang bernama Kukila dalam cerita Kukila (Rahasian Pohon Rahasia) karya M. Aan Mansyur. Langkah kedua yang dilakukan yaitu dengan memcatat bagian yang tadi sudah diberi tanda ketika membaca teks dan memindahkannya kedalam buku catatan agar menjadi lebih mudah dalam proses pengumpulan data yang dilakukan dalam penelitian ini yang kemudian akan dianalisis dan dideskripsikan oleh peneliti.

Penelitian ini menggunakan teknik analisis data kualitatif deskriptif. Analisis data merupakan proses pengumpulan data yang berkaitan dengan rumusan masalah dan tujuan penelitian. Analisis data dilakukan dengan cara kualitatif deskriptif berdasarkan kerangka berikir. Teknik deskriptif dalam penelitian ini yaitu data dikelompokkan sesuai dengan apa yang peneliti dapatkan dalam cerita yang berjudul Kukila.Selanjutnya, dilakukan analisis data yang dihubungkan dengan konteks yang ada dalam teks serta psikologi sastra agar mendapatkan implikasi-implikasi yang tepat dan sesuai dengan penelitian. Menurut Subana (2011) mengemukakan bahwa instrumen penelitian berkaitan dengan kegiatan dan pengolahan data, sebab instrumen penelitian merupakan alat bantu pengungumpulan dan pengolahan data tentang variabel-variabel yang diteliti. Maka dari itu, instrumen penelitian digunakan sebagai teknik pengumpulan data oleh peneliti.

\section{HASIL DAN PEMBAHASAN}

Dalam sebuah novelet yang berjudul cerita Kukila (Rahasia Pohon Rahasia) karya M. Aan Masnyur. Cerita ini terdapat empat penyimpangan dan enam faktor penyebab penyimpangan. Empat penyimpangan yang terjadi dalam tokoh Kukila yaitu: Derpresi, Axienty, Oppressed, Adultery dan tujuh faktor penyebab penyimpangannya yaitu Rumah tangga, Psikologi, Keluarga, Agama, Seksual, Sosial. Berikut kutipan dan penjelasan dari empat penyimpangan dan enam faktor penyebab penyimpangan yang ditemukan dalam cerita yang berjudul Kukila (Rahasia Pohon Rahasia) karya M. Aan Mansyur.

\section{Penyimpangan Psikologis}

\section{Depresi}

Pada bagian depresi ditemukan wujud penyimpangannya yaitu rasa bersalah yang mendalam, ditolak oleh anak, hidup sendirian di dalam rumah dan juga kenangan yang menghantuinya. Hal tersebut dapat dilihat pada kutipan di bawah ini.

"Ada keraguan yang tidak mampu Kukila gambarkan ketika amplop surat itu jatuh ke dalam bus surat. Ia seperti ingin memotong tangannya karena telah melakukan kesalahan besar yang tidak dapat termaafkan" (Mansyur, 2012).

Berdasarkan kutipan yang terdapat di atas, Kukila mengalami ketakutan yang berlebihan jika kata-kata yang ditulis dalam surat itu masih ada kata-kata yang akan menyakiti hati anak-anaknya. Terutama kesalahan yang Kukila lakukan membuatnya berpikir bahwa kesalahan itu tidak dapat dimaafkan oleh anak-anaknya. 
"Aku masih berdiri di situ saat tiba-tiba dua lagi pintu dibanting berturut-turut, mengagetkan aku. Setiap prak! Adalah tambahan ribuan "tidak" bagiku. Tanganku jatuh bagai daun-daun kering pohon manga" (Mansyur, 2012: 10).

Berdasarkan kutipan di atas Kukila mendapatkan penolakan dari ketiga anaknya yang tidak ingin lagi berbicara dengan Kukila ibunya sendiri. Atas penolakan itu Kukila mendapatkan penolakan hingga membuatnya depresi. Ketika ketiga anaknya pergi meninggalkannya hidup sendirian dalam kenangan dan rasa bersalahnya sepanjang waktu. Terdapat dalam kutipan dibawah ini.

"Kalian memilih membeli rumah baru, sendiri-sendiri; jalanan, warung, dan entah di mana lagi... "Kenangan terus tumbuh serupa hutan belantara. Di dapur. Di kamar mandi. Di beranda. Di halaman. Di tempat tidur. Di dinding. Di langitlangit. Di tangga. Bahakan suatu sore selepas mandi, aku menemukan kenangan tumbuh di kepalaku" (Mansyur, 2012: 12-13).

Berdasarkan pemaparan di atas, Kukila mengalami depresi karena ia hidup sendirian ditinggalkan oleh ketiga anaknya. Kukila juga mengalami depresi lainnya yang dialami karena terus-terusan mengingat peristiwa yang pernah dialami dikehidupannya di dalam rumah itu.

"Nak, dua hal yang aku benci dalam hidup: September dan pohon mangga. Di halaman, bunga-bunga butuh disiram. Pohon mangga batangnya tetap selutut. Aku pernah melihat ada tunas kecil tumbuh di situ, lalu kering dan mati. Pohon itu butuh bulan hujan, bukan September. Setiap sore, di beranda, aku duduk melihat taman sekarat, sementara kenangan tunbuh subur di mana-mana. Tentang rujak mangga. Tentang Rudi dan tawa kalian. Juga tentang rahasia-rahasia... "Rumah sepi serupa surau tua sejak Rusdi pergi. Tawa kalian kuduga ikut terlipat di koper-koper Rusdi dan terbawa ke kota lain. Kalian memilih membeli rumah baru, sendiri-sendiri: jalanan, warung, dan entah di mana lagi. Setelah lelah di luar rumah, pagi hari kalian menitip pejam pada bantal, lalu pergi lagi pada sore hari. Pagi tanpa sapa selamat pagi. Siang hari aku sendiri di meja makan. Malam aku sepi sempurna. Aku sungguh berumah dalam sepi." (Mansyur, 2012).

Berdasarkan kutipan di atas Kukila mengalami depresi atas perceraiannya dengan suaminya. Karena akibatnya anak-anaknya tidak mau lagi berbicara dengan Kukila ibunya sendiri. Kemudian ketiga anaknya pergi meninggalkannya sendiri. Kukila kesepian dan hidup sendiri didalam rumah yang penuh dengan kenangan. Kukila menyukai bulan September dan pohon mangga, karena bulan September mengingatkannya akan sebuah kenangan yang menyakitkan sedangkan pohon manga merupakan hadiah pernikahannya dengan Rusdi, ketika mereka bercerai mereka sepakat untuk menebang pohon manga itu. Namun, kenangan tidak pernah pergi melaikan membuatnya terus mengingatkannya ketika ia melihat pohon mangga yang berada didepan rumahnya. 
"Ia pergi karena aku. Ia tidak tahan lagi. Rusdi itu mandul. Kalian adalah anak-anak orang lain. Bukan anak-anak Rusdi." "Awalnya Rusdi sepakat aku tidur dengan lelaki itu. Tetapi aku mau punya satu anak lagi, seorang anak lelaki. Suatu pagi, ia menemukan aku melakukan lagi dengan orang itu"(Mansyur, 2012).

Berdasarkan kutipan di atas Kukila merasa bersalah atas perceraiannya denga Rusdi yang telah disepakatinya. Karena Kukila ingin mempunyai seoang putra maka Kukila melakukan hubungan terlarang lagi dengan Pilang, walaupun sebelumnya Kukila dan suaminya telah sepakat Kukila tidur dengan Pilang dan melahirkan anak.

"Pilang. Namanya aneh. Kau tahu artinya? Diam-diam aku pernah mencari namanya di kamus di perpustakaan sekolah, pada suatu hari. Ternyata kata itu berarti pohon yang tingginya bisa mencapai 25 meter. Dalam buku pelajaran biologi, ia bernama Acacia leucopholea, pohon akasia. Aku sangat mengahafalnya. Sungguh serasi ya? Aku seekor burung. Ia sebatang pohon. Lucu. Itu kemarin. Itu dulu. Sudah baerlalu. Seminggu lalu ia memutuskan untuk mengusirku dari dahannya entah karena apa. Sialan!” (Mansyur, 2012).

Berdasarkan kutipan di atas dijelaskan bahwa Kukila mengalami depresi akan jalinan cintanya dengan Pilang selesai tanpa alasan yang jelas, karena faktor penyebab jalinan kasih mereka berakhir karena ibu Pilang tidak merestui mereka dikarenakan mereka berbeda keyakinan.

"Mereka ingin kami memiliki anak. Pernikahan tanpa anak bagi mereka tidak menciptakan keluarga. Kau tahu? Mereka telah mengganggap pernikahan yang tidak dianugrahi anak sebagai pernikahan yang dikutuk. Pernikahan paling celaka" (Mansyur, 2012)

Berdasarkan kutipan di atas terlihat bahwa pernikahan Kukila dan Rusdi harus segera memiliki seorang anak karena faktor dari keluarga masing-masing yang ingin segera mempunyai penerus. Karena jika sebuah pernikahan tanpa seorang anak dianggap sebagai pernikahan yang dikutuk.

\section{Axienty}

Penyimpangan psikologi anxiety ditemukan suatu ancaman yang mengancam kenyamanan seseorang atau kecemasan yang di alami oleh Kukila pada surat yang ditulis dan dikirimkan untuk anak-anaknya.

Hilgard dalam Minderop (2010) berbagai konflik dalam bentuk perasaan berlebihan yang menghambat kemajuan seseorang dalam mencapai mencapai tujuan merupakan salah satu sumber ketakutan. Ancaman tersebut bisa berbentuk ancaman psikis ataupun ancaman fisik dan ancaman dari berbagai pihak. Hal tersebut dapat ditemukan dalam cerita Kukila (Rahasia Pohon Rahasia) sebagaimana dipaparkan oleh narator di bawah ini. 
"Di jalan menuju rumah, Kukila mengingat-ingat lagi semua kalimat yang ia tuliskan di suratnya. Apakah masih ada kalimat yang seharusnya dihapus dari sana? Apakah masih tersisa kata-kata yang tajam seperti mata pisau yang pernah melukai tangannya? Ia takut melukai hati anak-anaknya" (Mansyur, 2012).

Berdasarkan kutipan tersebut tokoh Kukila ketakutan jika kata-kata yang ditulis didalam suratnya masih ada kata-kata yang akan melukai hati ketiga anaknya. Hal ini menyebakan Kukila menjadi cemas akan kata-kata yang di tulis dalam suratnya itu.

\section{Oppressed}

Penyimpangan psikologi oppressed yaitu tentang pernikahan Kukila dengan Rusdi yang merupakan lelaki pilihan ayahnya. Konflik terjadi setelah dua tahun menikah Kukila belum memiliki seorang anak. Oppressed adalah kondisi psikologi yang mengalami tekanan dari berbagai pihak yang membuat pribadi tidak merasa nyaman dan terkenan akan yang diucapkan. Hal tersebut terjadi pada tokoh Kukila, seperti terdapat dalam kutipan dibawah ini.

"Mereka ingin kami memiliki anak. Pernikahan tanpa anak bagi mereka tidak menciptakan keluarga. Kau tahu? Mereka telah mengganggap pernikahan yang tidak dianugrahi anak sebagai pernikahan yang dikutuk. Pernikahan paling celaka" (Mansyur, 2012).

Berdasarkan kutipan di atas menjelaskan bahwa tokoh Kukila dalm cerita harus mempunyai anak karena sebuah pernikahan tanpa memiliki seorang anak di anggap sebagai pernikahan yang dikutuk dan paling celaka oleh keluarganya.

\section{Adultery}

Penyimpangan ini wujudnya yaitu sebuah perjinahan yang dilakukan Kukila atas permintaan Rusdi. Hal ini terjadi karena Rusdi tidak bisa memiliki anak dengan Kukila. Setelah Kukila memiliki seorang anak dari Pilang yang kemudian diakuinya sebagai anak Rusdi. Namun Kukila masih berselingkuh dengan Pilang hingga mempunyai anak ketiganya. Adultery atau bisa disebut dengan perjinahan yang dilakukan oleh seseorang yang sudah menikah dengan wanita lain. Perjinahan yang dilakukan biasanya terjadi karena rasa nyaman yang dialami oleh pasangan dengan satu sama lain mulai dari rasa keisengan kepada lawan jenis atau sekedar memuaskan nafsu yang ada (Kartini Kartono, 1989).

"Tetapi aku mau punya satu anak lagi, seorang anak lelaki. Suatu pagi, ia menemukan aku melakukan lagi dengan orang itu... "Kepada Kukila pernah aku katakan kami sudah memiliki dua orang anak. Sudah cukup. Dengan alasan yang kedengarannya sangat masuka akal, ia menginginkan anak lelaki, satu saja. Apakah ide itu darimu? Minggu lalu, sekali lagi, aku bertengkar dengan perdebatan yang sama. Aku tahu dua 
hari lalu kalian melakukannya lagi tanpa sepengetahuanku. Kau tidak perlu merahasiakannya. Aku tahu kalian sering melakukannya”(Mansyur, 2012).

Berdasarkan kutipan diatas Kukila melakukan hubungan terlarang dengan Pilang karena Kukila mempunyai keinginan untuk memiliki anak. Rusdi yang tidak dapat mempunyai anak dan tekanan dari orang tuanya membuat Rusdi dan Kukila memutuskan untuk memiliki anak-anak dari Pilang. Hal tersebut seharusnya tidak dilakukan meskipun terdapat kesepakatan antara suami dan istri. Kukila melakukan hubungan terlarang dengan pasangan tidak legal, yang tidak sesuai dengan norma yang berlaku dalam masyarakat. Pilang adalah mantan kekasih Kukila.

\section{Faktor Penyebab Penyimpangan}

\section{Faktor Rumah tangga}

Faktor rumah tangga yang dialami oleh tokoh Kukila dalam cerita yang berjudul "Kukila (Rahasia Pohon Rahasia) yang meliputi perceraian serta keinginan untuk mempunyai anak laki-laki. Seperti pada kutipan di bawah ini:

"Perceraian selalu diberi hadiah air mata, kado kesedihan. Selalu begitu adanya. Maafkan kami. Maafkan aku... "Rumah sepi serupa surau tua sejak Rusdi pergi. Tawa kalian kuduga ikut terlipat di koper-koper Rusdi dan terbawa ke kota lain. Kalian memilih membeli rumah baru, sendiri-sendiri: jalanan, warung, dan entah di mana lagi. Setelah lelah di luar rumah, pagi hari kalian menitip pejam pada bantal, lalu pergi lagi pada sore hari. Pagi tanpa sapa selamat pagi. Siang hari aku sendiri di meja makan. Malam aku sepi sempurna. Aku sungguh berumah dalam sepi”. (Mansyur, 2012).

Berdasarkan kutipan di atas, Kukila mengalami permasalahan rumah tangga berupa perceraian dengan suaminya. Kukila dan Rusdi akhirnya setuju untuk bercerai dan berpisah tanpa membahasan permasalahan yang terjadi diantara mereka dengan ketiga anaknya. Anak-anak mereka yang lalu tinggal bersama Kukila dan tidak pernah berbicara dengan Kukila juga tidak pernah berada di rumah. Setelah dewasa anak-anak Kukila kemudian meninggalkan Kukila. Kukila yang sudah mempunyai dua anak perempuan berharap kehadiran anak laki-laki. tetapi suaminya yang mandul tidak akan pernah bisa memberikan keturunan. Sehingga Kukila kembali berhubungan dengan Pilang, yang juga merupakan ayah dari kedua anak perempuannya.

\section{Faktor Psikologi}

Faktor psikologis yang dialami oleh Kukila yaitu kerahasiaan anaknya yang tidak diketahui oleh keluarganya dan Kukila merasa bahwa dirinya sumber masalah. Seperti pada kutipan dibawah ini:

“Aurora, Nawa, dan engkau satu-satunya anak lelakiku, Janu, aku merindukan kalian. Aku merindukan kalian seperti sungai kering di musim kemarau merindukan air 
mengaliri tubuhnya. Seperti akar-akar pohon merindukan hujan. Begitulah seorang ibu merindukan anak-anaknya"(Mansyur, 2012).

Berdasarkan kutipan di atas sebagai seorang ibu Kukila sangat merindukan ketiga anaknya. Ketika Kukila dan suaminya membuat keputusan untuk berpisah ketiga anaknya itu tidak mau lagi berbicara dengannya hingga ketiga anaknya tumbuh dewasa dan meninggalkannya. Rasa rindu yang di alami oleh Kukila sering membuatnya bermimpi akan ketiga anaknya menemuinya karena kerinduan tersebut membuatnya sering bermimpi bertemu anaknya hingga berkali-kali.

"Aku ingin mati di bulan September yang kemarau seperti bungabunga di halaman. Tetapi mati tidak bisa dipesan lalu seseorang mengantarnya serupa pesanan dari restoran cepat saji yang iklannya ada di televise"(Mansyur, 2012).

Berdasarkan kutipan di atas Kukila merasa bahwa dirinya adalah sumber kekacauan hingga kesulitan yang dialami dalam kehidupannya bersama suaminya. Karena kukila merasa bahwa dirinya sumber masalah hingga ia memilih untuk mengakhiri hidupnya karena jika ia hiduppun ia hanya hidup sendiri dan berteman dengan kesepian.

\section{Faktor Keluarga}

Faktor keluarga merupakan elemen yang terdiri dari orang tua serta suadara. Keluarga adalah suatu individu yang dimana berpengaruh sangat penting dalam kehidupan yang dialami untuk masa yang akan datang dan memberikan arahan dalam kehidupan. Sedangkan penyimpangan psikologis dalam faktor keluaga yang dialami oleh Kukila yaitu perjodohan dan tuntutan agar segera memiliki anak. Faktor keluarga merupakan salah satu faktor penyebab penyimpangan psikologis yang menimpa individu dikarenakan lingkungan keluarga misalnya perjodohan dan desakan orang tua agar segera memiliki anak. Perjodohan dialami oleh tokoh Kukila dalam cerita pendek Kukila (Rahasia Pohon Rahasia). Seperti pada kutipan dibawah ini:

"Bagaimanapun pernikahan kami akan berlangsung. Aku tidak tahu bagaimana cara menolaknya.... "Namun aku tidak mampu memenuhi kemauan orangtuanya dan orangtuaku. Mereka ingin kami memiliki anak. Pernikahan tanpa anak, bagi mereka, tidak menciptakan keluarga. Kau tahu? Mereka telah mengganggap pernikahan yang tidak dianugerahi anak sebagai pernikahan yang dikutuk. Kutukan paling celaka. Kau tahu, aku dan Kukila samasama anak tunggal. Orangtua kami meletakkan harapan satusatunya kepada kami agar generasi mereka berlanjut. Mereka tidak mau punah" (Mansyur, 2012)."

Berdasarkan kutipan di atas tokoh Kukila dalam cerita pendek Kukila (Rahasia Pohon Rahasia) mengalami sebuah perjodohan yang telah direncanakan oleh kedua orangtuanya. Kukila tidak mampu menolak perjodohan tersebut. Bukan hanya mengalami perjodohan, Kukila dan suaminya juga dipaksa untuk segera memiliki keturunan oleh kedua belah pihak keluarga. Hal tersebut didasari karena Kukila dan Rusdi merupakan anak tunggal 
dari kedua belah pihak. Orang tua mereka menganggap jika pernikahan yang tidak memliki keturunan merupakan pernikahan yang dikutuk.

\section{Faktor Agama}

Faktor agama yang merupakan sebuah kepercayaan kepada Tuhan, yang mengatur manusia yang ada di bumi. Faktor agama yang dialami Kukila yaitu mereka berbeda agama antara Kukila dan Pilang hingga akhirnya Pillang memilih untuk meninggalkan Kukila dan memutuskan cinta mereka.

"KUKILA-kukila-kukila. Namanya sangat indah. Aku sangat mencintainya. Tetapi aku tidak boleh mencintainya. Ibu marah setiap kali aku menyebut namanya. Kenapa harus seperti itu? Apakah karena kami berbeda agama? Agama. Agama. Agama. Agama. Mungkin itu yang membuat Ibu tidak mau mendengar nama Kukila. Apakah itu penting?"(Mansyur, 2012).

Berdasarkan kutipan di atas bahwa perbedaan agama menjadi suatu hal yang membuat orangtua Pilang tidak merestui Pilang untuk menjalin hubungan bersama Kukila yang beragama Islam. Karena agama mereka berbeda antara Kukila dan Pilang hinggan Pilang mengambil keputusan untuk berpisah dengan Kukia.

\section{Faktor Seksual}

Faktor seksual yang merupakan keinginan hubungan dalam sebuah keluarga yang harmonis didasari dengan cinta yang biasa dilakukan dalam hubungan rumah tangga seperti halnya berhubungan intim. Namun tokoh pertama yang bernama Rusdi mengalami penyimpangan seksual hal ini didasari oleh Rusdi tidak memiliki keinginan seksual terhadap dirinya dan juga kepada Kukila hal ini menyebabkan dirinya tidak dapat memiliki anak.

"Dua tahun sudah berlalu, tetapi demi Tuhan, aku tidak pernah punya gairah menjamah istriku. Aku tidak memiliki gairah bahkan untuk sekedar memeluk Kukila. Aku sudah mencobanya berkali-kali, tetapi aku tidak mampu. Kukila dimataku terlihat seperti adikku sendiri. Tidak perlu kau memberiku bermacam-macam saran dan tips dan trik atau apa pun namanya tentang bagaimana hal itu bisa kulakukan tidak akan ada gunanya. Aku sudah mencoba segala cara. Aku gagal. Baiklah, aku jujur saja. Kau, sekali lagi, mengerti siapa aku ini. Penisku tidak bisa berdiri untuknya, Pilang. Jangan tertawa!.... "Sejak kita SMP, aku menyukaimu. Kau mungkin tidak pernah sadar aku sering diam-diam mengamatimu dari balik pintu kelas. Bukan sekedar menyukaimu, aku mencintaimu. Aku tidak pernah menyampaikan perasaanku kepadamu"(Mansyur, 2012).

Berdasarkan kutipan di atas merupakan kutipan dari cerita pendek Kukila (Rahasia Pohon Rahasia). Dari kutipan tersebut tokoh Rusdi suami dari Kukila tidak memiliki keinginan seksual kepada Kukila. Rusdi telah melakukan berbagai macam usaha agar dapat dapat hubungan seks dengan Kukila tetapi tetap tidak berhasil. Rusdi yang merupakan laki- 
laki mandul dan ternyata memiliki orientasi selsual terhadap sesama jenis atau homoseksual.

\section{Faktor Sosial}

Faktor sosial yang merupakan keadaan sosial pada masyarakat yang ada disekitar, terutama berkaitan dengan kebudayaan dan norma-norma yang erat, karena jika dilanggar aka ada sanksi untuk orang yang melanggarnya dan mendapatkan hukuman mati terhadap siapa saja orang yang melarikan diri seperti yang terdapat dalam tokoh perempuan yang bernama Kukila dalam cerita Kukila (Rahasia Pohon Rahasia) bahwa Kukila tidak dapat pergi dari kampung halamannya bersama dengan Pilang laki-laki yang dicintainya karena takut dengan hukuman mati.

"Aku pikir orang tuamu pernah bercerita tentang hukuman seperti apa yang akan menimpa orang-orang yang berani melarikan diri dari kampung ini. Di sini, di cabangku, pernah sepasang kekasih digantung karena melanggar hukum adat-mereka mencoba lari, namun tertangkap di tengah jalan. Mereka diseret seperti binatang untuk dibawa ke tengah padang ini, dan di cabangku akhirnya mereka mati, dibiarkan berhari-hari seperti orang-orangan sawah. Aku dengar Pilang mengingatkan kisah tragis itu pada Kukila" (Mansyur, 2012).

Berdasarkan kutipan di atas dapat diketahui bahwa dalam orang-orang di kampung Kukila dalam cerita Kukila (Rahasia Pohon Rahasia), masih mempercayai hukum adat yang menyatakan siapa saja orang yang sengaja melarikan diri dari kampung tersebut akan mendapatkan hukuman yang sangat berat yaitu berupa kematian.

"Namun aku tidak mampu memenuhi kemauan orangtuanya dan orangtuaku. Mereka ingin kami memiliki anak. Pernikahan tanpa anak, bagi mereka, tidak menciptakan keluarga. Kau tahu? Mereka telah mengganggap pernikahan yang tidak dianugerahi anak sebagai pernikahan yang dikutuk. Kutukan paling celaka. Kau tahu, aku dan Kukila samasama anak tunggal. Orangtua kami meletakkan harapan satu-satunya kepada kami agar generasi mereka berlanjut. Mereka tidak mau punah"(Mansyur, 2012).

Berdasarkan kutipan di atas menjelaskan bahwa kepercayaan orangtua Kukila dan Rusdi tentang rumah tangga yang tidak memiliki keturunan adalah keluarga yang dikutuk, sehingga kedua belah pihak keluarga terus mendesak agar kukila dan Rusdi segera memiliki anak. Hal ini termasuk kepada faktor sosial antara keluarga Kukila dengan keluarga Rusdi.

\section{KESIMPULAN}

Dari hasil penelitian dan pembahasan mengenai penyimpangan psikologis tokoh perempuan dan faktor penyebab penyimpangan psikologis tokoh perempuan dalam cerita Kukila (Rahasia Pohon Rahasia) Karya M. Aan Mansyur ditemukan empat penyimpangan psikologis yaitu, pada bagian pertama depresi ditemukan wujud penyimpangannya yaitu, 
rasa bersalah yang mendalam, ditolak oleh anak, hidup sendirian didalam rumah dan juga kenangan yang menghantuinya. Kedua, yaitu pada penyimpangan psikologi anxiety ditemukan suatu ancaman yang mengancam kenyamanan seseorang atau kecemasan yang di alami oleh Kukila pada surat yang ditulis dan dikirimkan untuk anak-anaknya. Ketiga, yaitu penyimpangan psikologi oppressed yaitu tentang pernikahan Kukila dengan Rusdi yang dimana Rusdi merupakan lelaki pilihan ayahnya dan setelah dua tahun menikah Kukila belum memiliki seorang anak. Keempat, adultery dimana penyimpangan ini wujudnya yaitu sebuah perjinahan yang dilakukan Kukila tetapi atas permintaan Rusdi karena Rusdi tidak bias memiliki anak dengan Kukila. Setelah Kukila memiliki seorang anak dari Pilang namun di akuinya sebagai anak Rusdi namun Kukila masih berselingkuh dengan Pilang hingga mempunyai anak ketiganya.

Dalam cerita tersebut ditemukan enam faktor penyebab peyimpangan yang dialami tokoh Kukila, yaitu. Faktor yang pertama yaitu faktor rumah tangga yang dialami oleh tokoh Kukila dalam cerita yang berjudul Kukila (Rahasia Pohon Rahasia) yang meliputi perceraian serta keinginan untuk mempunyai anak laki-laki.

Faktor yang kedua yaitu faktor psikologis yang dialami oleh Kukila yaitu kerahasiaan anaknya yang tidak diketahui oleh keluarganya dan Kukila merasa bahwa dirinya sumber masalah.

Faktor yang ketiga yaitu faktor keluarga merupakan elemen yang terdiri dari orang tua serta suadara. Keluarga adalah suatu individu yang dimana berpengaruh sangat penting dalam kehidupan yang dialami untuk masa depan dan memberikan arahan dalam kehidupan. Sedangkan penyimpangan psikologis dalam faktor keluaga yang dialami oleh Kukila yaitu perjodohan dan tuntutan agar segera memiliki anak.

Faktor yang keempat yaitu faktor agama yang merupakan sebuah kepercayaan kepada Tuhan, yang mengatur manusia yang ada di bumi. Faktor agama yang dialami Kukila yaitu mereka berbeda agama antara Kukila dan Pilang hingga akhirnya Pillang memilih untuk meninggalkan Kukila dan memutuskan cinta mereka.

Faktor kelima yaitu faktor seksual yang merupakan keinginan hubungan dalam sebuah keluarga yang harmonis didasari dengan cinta yang biasa dilakukan dalam hubungan rumah tangga seperti halnya berhubungan intim. Namun dalam tokoh pertama yang bernama Rusdi mengalami penyimpangan seksual karena tidak memiliki gairah seksual terhadap dirinya dan kepada Kukila sehingga tidak dapat memiliki anak.

Faktor keenam yaitu faktor sosial yang merupakan keadaan sosial pada masyarakat yang ada disekitar, terutama berkaitan dengan kebudayaan dan norma-norma yang erat, karena jika dilanggar aka ada sanksi untuk orang yang melanggarnya dan mendapatkan hukuman mati bagi orang yang melarikan diri seperti yang terdapat dalam tokoh perempuan yang bernama Kukila dalam cerita Kukila (Rahasia Pohon Rahasia) bahwa Kukila tidak dapat pergi dari kampung halamannya bersama dengan Pilang laki-laki yang dicintainya karena takut dengan hukuman mati.

\section{DAFTAR PUSTAKA}

Andrian, S. N., \& Rifai, A. (2018). Ideologi Masyarakat Betawi Dalam Novel Kronik Betawi Karya Ratih Kumala. Jurnal Pendidikan Bahasa Indonesia, 6(1), 75-89. 
Anwar, C. (2007). Tradisi ziarah kubur masyarakat betawi pada makam Muallim KH. M. Syafi'i hadzami kampung dukuh jakarta Selatan.

Denisha, S. (2019). Habitus Maskulinitas Dalam Cerita Pendek “KUKILA” karya M. Aan Mansyur: Prespektif Pierre Bourdieu karya M. Aan Mansyur. Yogyakarta.

Dewi, T. U., \& Hidayatullah, S. (2018). Pengaruh Wawasan Sosok Buya Hamka dan Minat Menulis Terhadap Kemampuan Menulis Cerpen. In Prosiding Seminar Nasional Pendidikan (Vol. 1).

Diana, F. N. dan R. (2002). Mengembangkan Kreativitas dalam Perspektif Psikologi Islam. Yogyakarta: Menara Kudus.

Endraswara, S. (2011). Metode Penelitian Sastra. Yogyakarta: Medpress.

Hikmat, A., Puspitasari, N. A., \& Hidayatullah, S. (2017). Kajian Puisi. Jakart: Uhamka.

Kartini Kartono. (1989). Psikologi Abnormal dan Abnomarlitas. Bandung: Mandar Maju.

Lestari, A. K. (2020). Aspek Sosial dalam Novel Hujan Karya Tere Liye. Lingua Franca: Jurnal Bahasa, Sastra, Dan Pengajarannya, 4(1), 78-96.

Mansyur, A. (2012). Kukila. Jakarta: Gramedia.

Purba, A. (2010). Sastra Indonesia Kontemporer. Yogyakarta: Graha Ilmu.

Semi, M. A. (2012). Metode Penelitian Sastra. Bandung: CV. Angkasa.

Sugiyono. (2016). Metode Penelitian Kualitatif, Kuantitatif, dan R\&D. Bandung: Alfabeta.

Wellek, R., \& Warren, A. (1990). Teori Kesusastraan. Jakarta: Pustaka Jaya.

Wiyatmi. (2011). Psikologi Sastra. Yogyakarta: Pustaka. 